\title{
Promoting Wildlife Habitat and Conservation Partnerships Through State-Funded Grant Programs
}

\author{
CLAY B. BUCHANAN, ${ }^{1}$ Wildlife Division, Michigan Department of Natural Resources, 525 W. Allegan St., Lansing, MI \\ 48909, USA
}

\begin{abstract}
As hunter numbers decline nationally, state wildlife agencies look for new conservation funding avenues. With the assistance of conservation groups and engaged citizens, the Michigan Department of Natural Resources (MI DNR) was able to secure the passage of a restructured license package, which took effect in 2014. Included in the restructuring was a simplification of the available hunting licenses and a promise to give more back to state citizens for the resulting fee increases. Following up on this promise, the MI DNR Director directed the Wildlife Division to develop and initiate a grant program that would increase wildlife habitat through grant funds given to conservation partners. The Wildlife Habitat Grant Program awarded funds to the first round of successful applicants in spring of 2014, and this competitive grant program is now in its fourth cycle, with projects completed from Iron County in the western Upper Peninsula to Lenawee County in the southeastern Lower Peninsula. The Wildlife Habitat Grant Program has awarded >\$4.6 million and has improved or restored wildlife habitat on approximately 3,235 hectares (8,000 acres). As young forests are of high priority, a number of these projects have been focused on American woodcock (Scolopax minor) and ruffed grouse (Bonasa umbellus) habitat, and are often associated with Grouse Enhanced Management Sites (GEMS). Project collaborators have included the Ruffed Grouse Society and American Woodcock Society, U.S. Forest Service, Beaver Island Wildlife Club, National Wild Turkey Federation, Wildlife Management Institute, Soil and Water Conservation Districts, Michigan United Conservation Clubs (MUCC), and private landowners.
\end{abstract}

Proceedings of the American Woodcock Symposium 11: 103

KEY WORDS: conservation funding, grants, habitat, wildlife conservation

1 email: buchananc1@michigan.gov 